\title{
INTRODUCTION
}

\section{Discernment and the Christian Life}

The first part of this issue of the Acta Universitatis Carolinae Theologica is dedicated to the theme of discernment. The articles are part of the project 'Theological Anthropology in Ecumenical Perspective' (Charles University Research Centre No. 204052), and their first drafts were presented at a conference 'How Discernment between Good and Evil Shapes the Dynamics of the Human Journey' held in the Monastery of Bose in May 2019, and organised in cooperation with the Monastery. They come mainly from the younger generation of theologians from different Christian traditions, Roman Catholic, Protestant, and Orthodox. Before we introduce their specific contributions, let us briefly outline why the theme of discernment is so important in the life of Christians.

The essential human condition of being placed before a choice is expressed both in the Greek myth of Hercules at the crossroads and in the Bible. This situation implies a twofold condition: objectively, a real difference between choosing good and choosing evil; subjectively, the freedom of choice. If the objective condition is overwhelming, personal freedom vanishes, and individuals are doomed to follow either the good or the evil path. If individual freedom is the ultimate criterion, boundaries between evil and good are blurred, and freedom itself is but another name for the arbitrariness of power. What keeps the balance between ethical values and personal responsibility?

In the Christian tradition both in the East and the West, 'discernment' is the name of this process that we might call the art of choice, which safeguards both the transcendence of Good and the ultimate 
freedom of the human person. This discernment relies upon the responsibility of every person, believer, or agnostic. Human life itself imposes the choice among different attitudes, behaviours and actions, in order to be responsible for one's own existence and to live with awareness and responsibility. Discerning - from the Latin dis (between) and cernere (see clearly, distinguish) - is therefore an operation that calls for the consciousness of every human being. It determines his/her very identity.

In the Holy Scripture, God reveals to Israel his constitutive being before an option: 'I have placed you before life and death, blessing and curse.' God's commandment is always for life: 'Therefore choose life, that you may live ... loving the Lord, your God, obeying his voice and keeping you united with him' (Deuteronomy 30:15-16.19-20). You have to choose. Discernment is precisely this art of choice, to discern the present time, the kairós in which God works and speaks, the time of decision. There is a subject of discernment: it is the person and his or her freedom. The choice takes place in that secret place that the Bible calls the human heart, which is the conscience.

Throughout the centuries, the great Christian teachers and spiritual masters have taught the ways of discerning 'thoughts' (loghismoi in Greek, cogitationes in Latin), that distract the mind from seeking God and render it a prisoner of a deceptive image of oneself. Discernment is the personal and liberating operation that permits every person to recognise their unique vocation.

If discernment in itself concerns the person and their conscience, nevertheless it bears a collective dimension, which cuts across the social, cultural, political, and historical spheres. In the Christian tradition, discernment is above all 'ecclesial'. Every Christian community and every local Church are invited to be shaped by the Spirit of Christ (cf. Acts 2:1-11) and to discern the signs of the times, conforming renewal and fidelity to the 'deposit of faith'. Times of crisis have aroused, and still today should arouse, discernment (diákrisis). But the New Testament speaks clearly also of an object of discernment: the Christ himself. If in the Gospel the Lord asks to discern, to recognise the time (kairós) of his presence (cf. Luke 12:56-57), Paul will ask to discern the body of the Lord in the community that celebrates the Eucharist (1 Corinthians 11:28).

This ecclesial discernment, which gave shape to the decisions of the ecumenical councils, must always be exercised again today, when the 
Churches are committed to the path of recovering unity: it is necessary to discern together the truth, in theological dialogue, to recognise the common baptismal faith in Christ, overcoming the divisions created in history by linguistic, cultural, and political misunderstandings.

This art of choice becomes urgent today for the whole society, in an age of great change not only for faith, but also for ethics, culture, and the political life (we all live in the polis); an age of great uncertainties that often paralyses human choices, making men and women spectators of a life that does not belong to them; a life characterised by a complexity that they do not know how to master. This art of choice must therefore be rediscovered, practiced, and compared in different cultural worlds, with a view to a humanisation that contrasts all superficiality and disengagement: the un-politics and disengagement are always a prelude to barbarism.

Each of us is called to discern, sift, try, question, compare, and then choose and take a path, even at the risk of making mistakes: ethical awareness is an essential requirement of daily action and when it is not exercised, it is humanitas that is threatened. Of course, there are criteria for discernment: on the one hand, we need to build our own interiority, so that life is not exposed to instincts alone, but open to authentic freedom, always conditioned yet real; on the other hand, we need to set out in search of the common good, the good of the other, reading and interpreting history and its signs. For the Christian, among the various criteria, the primacy belongs to the word of God contained in the Holy Scriptures. But let us not forget that the Word of God and the Holy Spirit that accompanies it, according to the Catholic tradition, are never absent in the heart, in the conscience of every human being, Christian or not, religious or not religious. So, the question that accompanies each of us is: 'What have you done with your freedom?'

The articles collected in this issue approach the question from both the personal and communal side. They are focussed round two main sub-themes: how participation in the liturgical life helps to cultivate theological, moral, and spiritual discernment; and what other sources of practice and wisdom Christians of different traditions draw on, as they seek to live Christ-like lives and thus to make the right choices in the light of the Holy Spirit.

The emphasis on practice is deliberate, as in it we can see what beliefs and convictions really have authority for people. 'Words are deeds,' 
says Ludwig Wittgenstein. ${ }^{1}$ This could be seen as a paraphrase of the ancient axiom, lex orandi, lex credendi (the rule of faith [is] the law of belief), or in its longer form, lex orandi legem credendi constituit (the law of praying establishes the law of believing). ${ }^{2}$ Liturgical life presents precisely that form of practice, which informs belief, and as part of that informs also discernment. The first two articles consider how this happens.

Tabita Landová brings into conversation the theologies of Karl Barth and Walter Brueggemann and current liturgical and ritual scholarship. She reverses the position that ethical stances inform our moral actions and explores what we can learn about our actions as we participate in liturgy. Liturgy, according to her, teaches us to see the world through the perspective of the Kingdom of God. But the problem is that this is not always the case. In her text, she shows that this problem is also an advantage, as it protects us from false certainties. It requires a mutual relationship in which liturgical prayer forms and informs ethical convictions and moral practice, but also a critique going the other way round, when liturgy constructs or petrifies false worlds marked by unholy power interests. Landová points out that doubt can then have a constructive role, as it can be a starting point of discernment. The role of humility, she argues, does not consist in our blindness to injustice or to conflicts, but rather in awareness of the necessary partiality of each of our perspectives, something she sees liturgically expressed in the prayer for the Holy Spirit, on whom ultimately our life, our faith, and our sound discernment depends.

Michaela Vlčková places the discernment between good and evil outside of liturgy and of ritual, while exploring what she calls the 'anoetic' side of rituals, which is the dimension outside of intellect, which deeply engages the body. Complementing current ritual and liturgical studies with insights from patristic and medieval theology, she appreciates the stability of rituals, traditionally based, and doctrinally anchored. They are to provide certainty. And the nature of that certainty is important. Vlčková sees it as a kind of matrix, in which physical activity has a cosmological meaning, one which invites and cultivates religious

1 Ludwig Wittgenstein, Culture and Value (Oxford: Blackwell, 1998), 53e. Elsewhere he emphasises that it is dangerous to isolate and contemplate concepts - 'because the language game in which they are to be applied is missing'. Ludwig Wittgenstein, Philosophical Investigations 96 (Oxford: Blackwell, 1958).

2 See Prosper of Aquitaine, De vocatione omnium gentium, 1.12: PL 51, 664C. 
experience and gives meaning to the theological content. Christian liturgy consists in such practices, which make participation in God possible. On the other hand, she argues, it is necessary that people bring to that participation their life in a reflected manner, that they come as discerning people, inhabiting discerning communities. Without that, the outer forms of certainties supporting the 'anoetic' dimension of rituals would fossilise, and in effect, the ritual tradition would be emptied of its inner content.

The next article is composed as a conversation between three theologians: Kateřina Kočandrle Bauer, František Štěch, and Michaela Kušnieriková. They reflect on the problem of the fragmentation of discernment, on discernment and divine redemption, on the problem of the relationship with the origin of evil, and finally on the two factors relativising individual judgment, that of a community and that of eschatology. Drawing on Catholic, Orthodox, and Protestant sources does not necessarily follow the confessional affiliation of the speakers, but rather the flow of life they are immersed in. Out of that, the authors reflect on what they find helpful in their own traditions. The reader will encounter underlying differences related to the possibilities of the divine-human cooperation, to what is the aim for which people were created, to the differentiation between evil and sin, to the extent and the form by which human sin keeps harming people and the world in which we live, or to the understanding of grace, mercy and goodness. Like in the previous articles, the complex theological debate returns with reflection to the practical starting points regarding how to live with God a fruitful, true and good life.

Finally, the article of Viorel Coman provides a response to the three previous authors. He places the search for the gift and the wisdom of discernment into a contemporary context of new waves of secularism, populism, and doing away with the truth. Commenting on the form of a dialogue, he points out that together with the search for what discernment means in practice, a kind of meta-practical level inevitably comes in as well, as we reflect on the nature of the practices and traditions of wisdom, and their theological, moral, and spiritual dimensions. At the same time, he emphasises that already the method of a free exchange of opinions and experiences brings together the personal and the communal nature of the discussed subject. Coman thus illustrates why listening to the other, trying not to transpose his or her position to what is common in my own, is a necessary quality for 
any genuine common discernment and, indeed, for any healthy personal relationships. Moreover, as he points out, hearing others is vital for what he calls 'the twin-fidelities' of discernment: faithfulness to the tradition and faithfulness to the present life, and thus to innovation and newness. Coman then compares the dialogical approach of Kočandrle Bauer, Štěch, and Kušnieriková to the concept of 'open sobornicity' as developed by Fr Dumitru Stăniloae. Mutual exchange of gifts, when it comes to discernment, Coman argues, involves also a re-reading of the past, and learning from the instances of false discernment.

The articles in this issue do not and cannot exhaust such a complex topic as discernment, but hopefully, they provide the readers with windows into the current debate, and provoke further reflection and further conversations.

Brother Adalberto Mainardi, Monastery of Bose, and Ivana Noble, Prague

doi: 10.14712/23363398.2020.1 